\title{
LEISHMANICIDAL, TRYPANOCIDAL, AND CYTOTOXIC ACTIVITIES OF ENDOPHYTIC FUNGI ASSOCIATED WITH BIOACTIVE PLANTS IN BRAZIL
}

Luiz H. Rosa ${ }^{1}$; Vívian N. Gonçalves ${ }^{2}$; Rachel B. Caligiorne ${ }^{3}$; Tânia M. A. Alves ${ }^{2}$; Ana Rabello ${ }^{3}$; Policarbo A. Sales ${ }^{4}$; Alvaro J. Romanha ${ }^{4}$; Marcos E. G. Sobral ${ }^{5}$; Carlos A. Rosa ${ }^{6}$; Carlos L. Zani

${ }^{1}$ Laboratório de Microbiologia, Instituto de Ciências Exatas e Biológicas, Universidade Federal de Ouro Preto, Ouro Preto, MG, Brasil; ${ }^{2}$ Laboratório de Química de Produtos Naturais, Centro de Pesquisas René Rachou, Fundação Oswaldo Cruz, Belo Horizonte, MG, Brasil; ${ }^{3}$ Laboratório de Pesquisas Clínicas, Centro de Pesquisas René Rachou, Fundação Oswaldo Cruz, Belo Horizonte, MG, Brasil; ${ }^{4}$ Laboratório de Parasitologia Celular e Molecular, Centro de Pesquisas René Rachou, Fundação Oswaldo Cruz, Belo Horizonte, MG, Brasil; ${ }^{5}$ Departamento de Botânica, Instituto de Ciências Biológicas, Universidade Federal de Minas Gerais, Belo Horizonte, MG, Brasil; ${ }^{6}$ Departamento de Microbiologia, Instituto de Ciências Biológicas, Universidade Federal de Minas Gerais, Belo Horizonte, MG, Brasil.

Submitted: April 07, 2009; Returned to authors for corrections: July 13, 2009; Approved: February 18, 2010.

\begin{abstract}
One hundred and twenty-one isolates of endophytic fungi were recovered from leaves of the bioactive Brazilian plant species Ageratum myriadenia, Palicourea tetraphylla, Piptadenia adiantoides, and Trixis vauthieri. All fungal isolates were cultivated in liquid media and crude extracts were obtained with ethyl acetate. The crude extracts were tested in bioassay panels using Leishmania amazonensis, Trypanosoma cruzi, the enzyme trypanothione reductase (TryR) from Trypanosoma cruzi, and three human cancer cell lines. Thirty-three extracts $(27.2 \%)$ exhibited at least one biological activity. Seventeen extracts (14\%) were cytotoxic against one or more human cancer cell line with the $\mathrm{IC}_{50}$ values ranged of $>0.2$ to 25 $\mu \mathrm{g} / \mathrm{mL}$. Twenty-four extracts (19.8\%) inhibited the activity of TryR, and three showed ability to inhibit the growth of $T$. cruzi above $60 \%$ and their $\mathrm{IC}_{50}$ values ranged among 1 to $10 \mu \mathrm{g} / \mathrm{mL}$. Eleven extracts $(9 \%)$ were able to inhibit the growth of $L$. amazonensis and showed with $\mathrm{IC}_{50}$ values ranged among 4.6 to 24.4 $\mu \mathrm{g} / \mathrm{mL}$. The endophytic fungi were identified as belonging to the genera Alternaria, Arthrinium, Cochliobolus, Colletotrichum, Penicillium, Fusarium, and Gibberella. An interesting result was obtained for the bioactive isolates UFMGCB 508, 537, 899 and 903, which were related to fungi associated with medicinal plants native to Asia, Australia, Africa, and Polynesia. These results indicate that bioactive plants living in Brazilian ecosystems are a potential host of endophytic fungi able to produce bioactive prototype molecules for drug development against neglected tropical diseases.
\end{abstract}

Key words: Endophytic fungi, human tumoral cell, Leishmania, secondary metabolites, Trypanosoma cruzi

\footnotetext{
*Corresponding Author. Mailing address: Laboratório de Microbiologia, Universidade Federal de Ouro Preto, Rua Diogo de Vasconcelos, 122, Ouro Preto, MG, CEP 35.400-000, Brazil.; Tel.: +55-31-3559 1695 Fax: +55-31-3559 1633.; E-mail: 1hrosa@ufop.br
} 


\section{INTRODUCTION}

Endophytic fungi are found in almost all plants, including trees, grasses, and herbaceous plants. Most endophytic fungi belong to the Ascomycota and their anamorphic stages, which live asymptomatically in plant tissues (12). These fungi have also been recognised as a repository of novel secondary metabolites of pharmaceutical importance. Fifty-one percent of the biologically active substances obtained from these microorganisms were previously unknown $(26,29)$, and the broad diversity and taxonomic spectrum exhibited by these fungi make them especially interesting for secondary metabolite screening programs.

According to Strobel (29), reasonable hypotheses should govern the plant selection strategy for the discovery of bioactive endophytic fungi; one of these includes plants that exhibit medicinal or pharmacological activities. Recent studies have demonstrated that endophytic fungi living in medicinal plants exert a wide range of biological activities (12, 20). However, there is little information on the fungal endophyte communities associated with bioactive plants living in Brazilian ecosystems. In this study four plants known for their biological activities were selected to endophytic fungi recovered. Palicourea tetraphylla has been used in traditional Brazilian medicine to treat tumours of joints and limbs, and indurations of the prostate (11); Piptadenia adiantoides, popularly known as "Calombi-branco" is used as food and for handcrafting (4); Ageratum myriadenia produce metabolites with cytotoxic and trypanocidal activities (27); and Trixis vauthieri has the ability to produce trixol, a trypanocidal compound active against the protozoan tropical parasite $T$. cruzi (22).

In previous studies, we showed that the fungi isolated from Brazilian ecosystems are able to produce bioactive secondary metabolites against pathogenic microorganisms (23, 24), Trypanosoma cruzi, and human tumour cells $(5,25)$. In connection with our program to discover bioactive fungal metabolites, this study focuses on the ability of endophytic fungi recovered from the pharmacological plants $A$. myriadenia, $P$. tetraphylla, $P$. adiantoides, and $T$. vauthieri to produce secondary metabolites with cytotoxic, leishmanicidal, and trypanocidal activities.

\section{MATERIAL AND METHODS}

\section{Sample collection}

Plants were collected in the Private Natural Heritage Reserve of the Sanctuary of the Caraça (20 $05^{\prime}$ S and $\left.43^{\circ} 27^{\prime} \mathrm{W}\right)$, which is situated in the Espinhaço Mountain region and includes the biomes Brazilian Savanna ("Cerrado") and highaltitude plateaus ("Campo de Altitude") in Minas Gerais state, Brazil. Healthy leaves were collected from Ageratum myriadenia (DC) R.M. King \& H. Rob., Palicourea tetraphylla Cham. \& Schltdl., Piptadenia adiantoides (Sprengel) Macbr., and Trixis vauthieri DC. The fresh-cut ends of plant samples were were stored in sterile plastic bags and transported under refrigeration to the laboratory over a period of no more than 24 h. All plant vouchers were deposited at the herbarium of the Institute of the Ciências Biológicas (BHCB) of the Universidade Federal of Minas Gerais, Brazil (http://sciweb.nybg.org/science2/IndexHerbariorum.asp).

\section{Fungal isolation}

A surface sterilisation method was used, consisting of successive dipping of leaf fragments in 2\% Extran (Sigma, USA) detergent (2 $\mathrm{min}), 70 \%$ ethanol (1 $\mathrm{min})$, household bleach with a final sodium hypochlorite concentration of $2 \%$ (3 $\mathrm{min})$, and washing with sterile distilled water (2 $\mathrm{min})$. The sterilised fragments were placed on Petri plates containing potato dextrose agar (PDA, Difco, USA) plus chloramphenicol at $100 \mathrm{mg} / \mathrm{mL}$. The plates were incubated up to 60 days, and individual fungal isolates were purified on PDA plates. The isolates were stored at $4{ }^{\circ} \mathrm{C}$ in PDA tubes. Mycelial fragments from each isolate were also preserved in $30 \%$ glycerol sterile aqueous suspension at $-80^{\circ} \mathrm{C}$. All fungal isolates were deposited in the Collection of Microorganisms and Cells of the Universidade Federal of Minas Gerais, Brazil under code UFMGCB.

\section{Preparation of fungal extracts}

The fermentation and crude extract fungi productions for 
secondary metabolites recovered were previous established by by Rosa et al. (24). Briefly, Pre-inocula for the cultures were prepared by aseptically transferring three $5 \mathrm{~mm}$ discs from each microorganism on MEA (2\% malt extract, $0.1 \%$ peptone, $1.5 \%$ glucose, and $1.5 \%$ agar) slants into unbaffled $250 \mathrm{~mL}$ Erlenmeyer flasks containing $25 \mathrm{~mL}$ MEC medium (2\% malt extract, $0.1 \%$ peptone, $1.5 \%$ glucose). The flasks were shaken at 150 r.p.m. and $28^{\circ} \mathrm{C}$ for five days. The fungal growth of the pre-inoculum flasks was transferred to $250 \mathrm{~mL}$ Erlenmeyer flasks containing $100 \mathrm{~mL}$ MEC. The inoculated flasks were shaken at 150 r.p.m at $28^{\circ} \mathrm{C}$ for nine days. After this incubation, the flasks were frozen $\left(-20^{\circ} \mathrm{C}\right)$ until extraction. The mycelium was separated from the culture broth by vacuum filtration and the filtrate was extracted with ethyl acetate. After drying with anhydrous sodium sulphate, the solvent was removed in a rotary-evaporator (Büchi model R-114) under vacuum and temperatures below $45^{\circ} \mathrm{C}$. The crude extract was further dried in a vacuum centrifuge at $35^{\circ} \mathrm{C}$ for $24 \mathrm{~h}$ and stored at $-20^{\circ} \mathrm{C}$ until assayed. Crude extract stock solutions at $20 \mathrm{mg} / \mathrm{mL}$ were prepared in dimetil sulphoxide (DMSO, Meck/USA) and stored at $-40^{\circ} \mathrm{C}$. These solutions were diluted with water and assayed at the final concentration of $20 \mu \mathrm{g} / \mathrm{mL}$, with the DMSO concentrations kept below $0.1 \%$.

\section{Assay with Leishmania amazonensis}

Promastigotes of Leishmania (Leishmania) amazonensis (strain IFLA/BR/196/PH-8) were obtained from lesions of infected hamsters. The parasites were grown at $26^{\circ} \mathrm{C}$ in $\mathrm{pH} 7.2$ Schneider's medium and then stimulated to differentiate into amastigote-like forms by increasing the temperature $\left(32^{\circ} \mathrm{C}\right)$ and lowering the $\mathrm{pH}$ (6.0) of the medium. After seven days under these conditions, $90 \%$ of the promastigotes were transformed into amastigote-like forms, which were then used in the bioassays. Amastigote density was adjusted to $1 \times 10^{8}$ parasites per $\mathrm{mL}$, and $90 \mu \mathrm{L}$ was added to each well of 96-well plates. Ten microliters of compounds and control solutions were added to attain the desired concentrations. The plates were incubated at $32^{\circ} \mathrm{C}$ for $72 \mathrm{~h}$, and then cell viability was determined using the MTT $(5 \mathrm{mg} / \mathrm{mL})$ assay (31). The results are expressed as percent inhibition in relation to controls without drugs. Amphotericin B at $0.2 \mu \mathrm{g} / \mathrm{mL}$ (Fungison ${ }^{\circledR}$ Bristol-Myers Squibb B, Brazil) was used as a positive drug control. All assays were performed in triplicate.

\section{Assay with the recombinant enzyme trypanothione reductase (TryR) from Trypanosoma cruzi}

The colorimetric assay was performed in 96-well plates according to the protocol established by Hamilton et al. (10). After incubating the enzyme with the samples and controls at $30^{\circ} \mathrm{C}$, Elman's reagent [5,5'-dithio-bis(2-nitrobenzoic acid)] was added, and the absorbance at $412 \mathrm{~nm}$ was measured for 5 $\min$ at $12-\mathrm{s}$ intervals. The slope of the curve $(\delta \mathrm{Abs} / \delta \mathrm{t})$ thus obtained was taken as a measure of enzyme activity, and the percentage of enzyme inhibition was calculated by comparing this value with the slope obtained for controls without drugs. Clomipramine, a known TryR inhibitor (3), was used at 16 $\mu \mathrm{g} / \mathrm{mL}$ as a control drug. It has been used as the reference compound against which to compare the potency of newly tested substances. The experiments were repeated twice.

\section{In vitro assay with amastigote intracellular forms of Trypanosoma cruzi}

In vitro assay with amastigote forms of $T$. cruzi was performed according protocols established by Buckner et al. (2) with modifications. Briefly, parasites and culture procedures: T. cruzi (Tulahuen strain) expressing the Escherichia coli $\beta$-galactosidase gene were grown on monolayer of mouse L929 fibroblasts. Cultures to be assayed for $\beta$-galactosidase activity were grown in RPMI 1640 medium ( $\mathrm{pH}$ 7.2-7.4) without phenol red (Gibco BRL) plus $10 \%$ fetal bovine serum and glutamine. Ninety-six well tissue culture micro plates were seeded with L929 fibroblasts at $4.0 \times 10^{3}$ per well in $80 \mu \mathrm{L}$ and incubated overnight. $\beta$-galactosidaseexpressing trypomastigotes were then added at $4.0 \times 10^{4}$ per well in $20 \mu \mathrm{L}$. After $2 \mathrm{~h}$, the medium with trypomastigotes that not penetrated in cells was discarded and replaced by $200 \mu \mathrm{L}$ of fresh medium. After $48 \mathrm{~h}$, the medium was discarded again and replaced by $180 \mu \mathrm{L}$ of fresh medium and test compounds in 20 
$\mu \mathrm{L}$. Each extract was tested in triplicate. After 7 days of incubation, chlorophenol red $\beta$-D-galactopyranoside (CPRG) (100 $\mu \mathrm{M}$ final concentration) and Nonidet P-40 (0.1\% final concentration) were added to the plates and incubated overnight at $37^{\circ} \mathrm{C}$ and the absorbance measured at $570 \mathrm{~nm}$ in an automated micro plate reader. Benzindazole at its $\mathrm{IC}_{50}(1$ $\mu \mathrm{g} / \mathrm{mL}$ ) was used as positive control. The results are expressed as percentage growth inhibition.

\section{Assay with human cancer cell lines}

The effect of crude extract on the survival and growth of the human cancer cell lines UACC-62 (melanoma), MCF-7 (breast), and TK-10 (renal) was determined using a colorimetric method developed at the National Cancer Institute-USA (17). Briefly, cells were inoculated in 96-well plates and allowed to stabilize for $24 \mathrm{~h}$ in a $\mathrm{CO}_{2}$ incubator at $37^{\circ} \mathrm{C}$. Solutions of extracts were added to attain the desired concentrations, and plates were incubated for $48 \mathrm{~h}$ under the same conditions. Trichloroacetic acid was added to each well to precipitate the proteins, which were quantified in a colorimetric assay using the dye sulphorodamine B. All assays were run in triplicate wells and repeated at least once. Etoposide at $16 \mu \mathrm{g} / \mathrm{mL}$ and cancer cell lines without fungal extracts were used in parallel as positive and negative controls, respectively. Results are expressed as percentage of growth inhibition in comparison to the control without drug.

\section{Statistical analysis}

The software GraphPad Prism version 4.03 was used to calculate the $\mathrm{IC}_{50}$ values using the non-linear curve fitting of two or more independent experimental datasets to a four parameter logistic dose-response model. No constraints were applied to the curve fitting calculations.

\section{DNA extraction, amplification and sequencing}

For DNA extraction, approximately $1.5 \mathrm{~cm}$ of mycelium growth was transferred to $2 \mathrm{~mL}$ sterile tubes (Eppendorf) with $400 \mu \mathrm{L}$ of extraction buffer solution (0.05 M Tris-HCl, $50 \mathrm{mM}$ Na-EDTA, $1 \mathrm{mM} \mathrm{NaCl}$, and $1 \% \mathrm{SDS}$ ), frozen at $-20^{\circ} \mathrm{C}$ overnight, and triturated vigorously. After adding $5 \mu \mathrm{L}$ of proteinase K (Sigma-Aldrich/USA), the material was shaken and incubated for $12 \mathrm{~h}$ at $37^{\circ} \mathrm{C}$. After incubation, $162 \mu \mathrm{L}$ of CTAB-Buffer (200 mM Tris $\mathrm{HCl}, \mathrm{pH}$ 7.5; 200 mM Na-EDTA, $8.2 \% \mathrm{NaCl}, 2 \% \mathrm{CTAB})$ was added, and the mixture was vortexed vigorously and incubated for $10 \mathrm{~min}$ in $65^{\circ} \mathrm{C}$. Chloroform/isoamilic alcohol $(24: 1 ; 570 \mu \mathrm{L})$ was added, then the mixture was vortexed vigorously, incubated for $30 \mathrm{~min}$ at $0^{\circ} \mathrm{C}$, and centrifuged for $10 \mathrm{~min}$ at 14,000 r.p.m. After transferring the aqueous supernatant (approximately $400 \mu \mathrm{L}$ ) to a new $1.5 \mathrm{~mL}$ Eppendorf tube, $40 \mu \mathrm{l}$ of $3 \mathrm{M}$ sodium acetate was added and incubated for $1.5 \mathrm{~min}$ at $0^{\circ} \mathrm{C}$, and centrifuged for $10 \mathrm{~min}$ at 14,000 r.p.m. The supernatant was transferred to a new $1.5 \mathrm{~mL}$ Eppendorf tube, and 50\% isopropyl alcohol was added, centrifuged for $5 \mathrm{~min}$ at 14,000 r.p.m., and the supernatant discarded. The pellet was washed twice with 200 $\mu \mathrm{L} 70 \%$ ethanol at $10^{\circ} \mathrm{C}$. DNA was dried overnight at room temperature, suspended in TE-buffer $(10 \mathrm{mM}$ Tris, $10 \mathrm{mM} \mathrm{Na}$ EDTA, $\mathrm{pH} 8.0$ ), incubated for $60 \mathrm{~min}$ at $65^{\circ} \mathrm{C}$, and stored in a refrigerator.

The ITS domains of rRNA gene were amplified with the universal primers ITS1 (5'-TCCGTAGGTGAACCTGCGG-3') and ITS4 (5'-TCCTCCGCTTATTGATATGC-3') as described by White et al. (33). Amplification of ITS were performed as follows: $95^{\circ} \mathrm{C}$ for $5 \mathrm{~min}$, followed by 39 cycles consisting of $94^{\circ} \mathrm{C}$ for $60 \mathrm{~s}, 50^{\circ} \mathrm{C}$ for $60 \mathrm{~s}$, and $72^{\circ} \mathrm{C}$ for $60 \mathrm{~s}$, and a final extension at $72^{\circ} \mathrm{C}$ for $5 \mathrm{~min}$. The amplified DNA was concentrated, cleaned using the kit Wizard Plus SV Minipreps DNA Purification System (Promega, USA), and sequenced in a MegaBACE $^{\mathrm{TM}} 1000$ automated sequencing system (Amersham Biosciences, USA). The sequences obtained were adjusted using SeqMan П of Lasergene software (DNASTAR/Inc.), and a consensus sequence was obtained using the software Bioedit v. 7.0.5.3. To reach species level identification by rRNA gene sequencing, the consensus sequence was aligned with all sequences of related species retrieved from GenBank database using the Fasta 2.0 program (1). After sequencing, the consensus sequences were deposited in GenBank under the accession numbers FJ466701 to FJ466730. Phylogenetic 
relationships were estimated using MEGA program Version 4.0 (30). The phylogenetic trees were constructed using the neighbour joining (NJ) algorithm with bootstrap values calculated from 1,000 replicate runs. The Maximum Composite Likelihood model was used to estimate evolutionary distance.

\section{RESULTS AND DISCUSSION}

In this study, crude extracts of 121 fungal endophytes were obtained from four pharmacological plants present in Brazilian ecosystems, which were tested in different biological assay models. Eight bioactive isolates were recovered from $A$. myriadenia, 10 from $P$. tetraphylla, 10 from $P$. adiantoides, and five from $T$. vauthieri (Table 1). Thirty-three extracts (27.2\%) exhibited at least one biological activity. Among the active extracts, 17 (14\%) inhibited cellular growth by more than $60 \%$ for one or more human cancer cell lines. The extracts from endophytic isolates UFMGCB 508, 523, 533, 536, and 554 exhibited $100 \%$ inhibition against all tumour cell lines tested. Fungal extracts from UFMGCB 540, 899, and 903 isolates were active only against the tumour cells. The extracts that showed cytotoxic activities $\geq 90 \%$ were tested to determine the $\mathrm{IC}_{50}$ values, which ranged of $>0.2$ to $25 \mu \mathrm{g} / \mathrm{mL}$ (Table 4 ). The extracts that showed selective activities against tumoral cells and the best $\mathrm{IC}_{50}$ values $(>2 \mu \mathrm{g} / \mathrm{mL}$ ) will be selected to isolation of their bioactive compounds.

Twenty-four (19.8\%) fungal extracts inhibited by more than $60 \%$ the activity of TryR, a key enzyme that helps Trypanosoma and Leishmania parasites to maintain a reducing intracellular environment by reducing its natural substrate trypanothione disulphide (10), and is a potential target for trypanocidal and leishmanicidal drugs. The highly selective activities of isolates UFMGCB 518, 525, 531, 538, and 569 against TryR suggest the presence of trypanocidal compounds in the extracts of these fungi. The extracts that showed actives $\geq 90 \%$ in TryR assays were tested against T. cruzi (Table 2). Among these, three extracts produced by endophytic isolates UFMGCB 508, 533, and 536 showed abilities to inhibit more or equal $60 \%$ the growth of $T$. cruzi. The $\mathrm{IC}_{50}$ of these extracts were determinate and ranged of 1 to $10 \mu \mathrm{g} / \mathrm{mL}$ (Table 4 ). The best crude extract was produced by the endophytic isolate UFMGCB 508 with activity of $1 \mu \mathrm{g} / \mathrm{mL}$, the same value of drug control benznidazole and will be selected to isolation of trypanocidal compounds.

Extracts of isolates UFMCB 508, 509, 513, 529, 563, 579, and 648 inhibited TryR and were active against amastigote forms of L. amazonensis. Isolate UFMGCB 908 was obtained from the trypanocidal plant $T$. vauthieri and inhibited TryR activity by $87 \%$. Eleven (9\%) fungal endophyte extracts were able to inhibit the growth of amastigote forms of $L$. amazonensis more than $60 \%$. Two fungal extracts obtained from isolates UFMGCB 529 and 910 inhibited the growth of $L$. amazonensis by more than $90 \%$. The best active extracts were submitted to $\mathrm{IC}_{50}$ determination, which range of 4.6 to 24.4 $\mu \mathrm{g} / \mathrm{mL}$ (Table 4). Isolate UFMGCB 914 was able to produce a crude extract with highly selective leishmanicidal activity. All leishmanicidal extracts will be submitted to isolation of bioactive compounds.

All bioactive endophytic fungi recovered from leaves of bioactive plants did not produce conidia or spores (mycelia sterilia) in common mycological media tested (malt extract agar, potato dextrose agar, and Sabouraud's dextrose agar). According Phongpaichit et al. (20) the most of endophytic fungi did not produce sexual or asexual microstructures in culture media and only could be identified by molecular methods. Thus, our strategy was to identify these mycelia sterilia by means of rRNA gene sequence comparison (assessment of percentage nucleotide identities with reference sequences) as well as phylogenetic analysis. In this work, fungal molecular identification based on ITS sequence analysis revealed that the most active isolates belong to Arthrinium Kunze (12 isolates), Penicillium Link (four isolates), Gibberella Sacc. (three isolates), Uncultured fungus (three isolates), Endophytic fungi (three isolates), Alternaria Nees, Fusarium Link ex Gray, Cochliobolus, and Colletotrichum Corda, each with one isolate (Table 3).

Eleven isolates were identified as species belonging to the genus Arthrinium, which includes species described as 
producers of secondary metabolites with biological activities such as arthrichitin and CAF-603 (antifungal), terpestacin (cytotoxic), and the xanthone derivative norlichexanthone (antioxidant) (21). Arthrinium species are found as phytopathogens, opportunists, or endophytic fungi. Nine isolates were similar to Arthrinium sp. (GenBank accession number AM922206), a strain recovered from the perennial grass Dactylis glomerata (Poaceae) which is native to the temperate zones of Europe and Asia (16), and was used in folk medicine against cancer (8). Four isolates were more than $97 \%$ identical to Penicillium species, and identified as $P$. citrinum UFMGCB 518, Penicillium sp. UFMGCB 523, Penicillium sp. UFMGCB 579, and P. dipodomyicola UFMGCB 654. Penicillium species can be pathogens, saprobes, opportunists, or endophytes of plants in natural environments (20), and many species of this genus produce different groups of bioactive secondary metabolites (32). The ITS regions of isolates UFMGCB 533, 536, and 648 exhibited more than $99 \%$ identity to Gibberella sp. (GenBank accession number EU552131) and the isolate UFMGCB 529 was $99 \%$ identical to Fusarium oxysporum (GenBank accession number DQ535184). Gibberella species are plant pathogens, although many are more familiar under their Fusarium anamorph names, which are the most commonly reported endophytes of wild plants (14). The complex Gibberella/Fusarium species produce several biologically active metabolites such as fusaric acid, moniliformin, fumonisins, zearalenon, enniatins, trichothecenes, and others (7).

The ITS regions of isolates UFMCB 554 and UFMGCB 564 were $95 \%$ and $89 \%$ identical to Bipolaris zeicola and Cochliobolus melinidis, respectively. The genus Bipolaris (anamorphous of Cochliobolus) contains about 45 species which are mostly subtropical and tropical plant parasites; in this study, these two genera were found as endophytes in healthy tissues of $P$. adiantoides. Some bioactive natural products were isolated from Bipolaris/Cochliobolus species. Different species of Cochliobolus and Bipolaris produce phytoxin ophiobolins (34). Isolate UFMGCB 611 had 98\% identity with Colletotrichum boninense (GenBank accession number EU822802). Inácio et al. (13) recovered $C$. gloeosporioides from leaves of Cryptocarya mandioccana Nees (a Brazilian Atlantic Forest plant species), which was able to produce antifungal metabolites against phytopathogenic fungi. Colletotrichum species recovered from Artemisia annua (15) and Palicourea longiflora leaves (27) are antimicrobial metabolites producer. Isolate UFMGCB 563 was $98 \%$ identical in the ITS region with Alternaria arborescens (GenBank accession number AY154706). Species of Alternaria can be found as endophytic fungi in different plant species (6), and are able to produce about 70 bioactive secondary metabolites (18).

The ITS regions of three isolates matched best with uncultured clone fungi: isolates UFMGCB 508, 537, and 568 were similar to uncultured fungi. An interesting result was obtained for the isolates UFMGCB 508 and UFMGCB 537, which exhibited $97 \%$ and $98 \%$ identity, respectively, with an Uncultured fungus (GenBank accession number AJ877196) that was recovered from leaves of the Heterosmilax japonica Kunth, known pharmaceutical plant used in Chinese traditional medicine (9). The phylogenetic analysis of the isolates UFMGCB 508 and 537 showed only seven (1.4\%) and one $(0.2 \%)$ nucleotide differences in the ITS region, respectively, when compared to the Uncultured fungus (GenBank accession number AJ877196) from the H. Japonica (Figure 1). The isolate UFMGCB 568 present showed 98\% sequence identity and five $(1 \%)$ nucleotide differences in the ITS region to an Uncultured endophytic fungus (GenBank accession number EF505005) recovered from Zea mays (maize) (19).

Isolates UFMGCB 899, 903, and 914 were related to three Unidentified endophytic fungi (identities ranging of 92 to $99 \%$ ) recovered in tropical grasses with GenBank accession numbers EU687163, EU687084, and EU687185, respectively. However, the isolate UFMCB 899 showed $96 \%$ identities in the ITS region to Xylaria sp. D61 (GenBank accession number EU099587) recovered from leaves of Garcinia dulcis Kurz., native to Asia, Australia, Africa, and Polynesia, which showed antibacterial, antimalarial, cytototicity, and antiproliferation activities (20). The isolate UFMGCB 903 presented $97 \%$ identity and in phylogenetic analysis (Figure 2) eight (1.7\%) 
nucleotides difference in ITS rRNA gene sequences with Xylaria sp. S20 (GenBank accession number EU678657) an endophytic fungus recovered from Dendrobium nobile Lindl. a famous Chinese traditional medicinal orchid (35). The taxonomic position of the bioactive isolates UFMGCB 540, 553, 569, and 910 could not be determined by ITS sequences, and further taxonomic studies will be conducted to determine their taxonomic positions.

The results from this study have clearly confirmed the high diversity of endophytic fungi producing bioactive compounds in these bioactive plants living in Brazilian biomes. Endophytic fungi obtained from plants A. myriadenia, $P$. tetraphylla, $P$. adiantoides, and $T$. vauthieri could be a promising source of antitumoral, leishmanicidal, and trypanocidal prototype secondary metabolites, which could be a pipeline for the development of new drugs. The promising crude extract, which showed the best $\mathrm{IC}_{50}$ values and selective activities, will be selected to isolation of actives compounds.

Table 1. Fungal crude extracts which biological activities above $60 \%$ when tested at $20 \mu \mathrm{g} / \mathrm{mL}$ against human tumour cells, the recombinant enzyme trypanothione reductase (TryR), and amastigote forms of the Leishmania amazonensis.

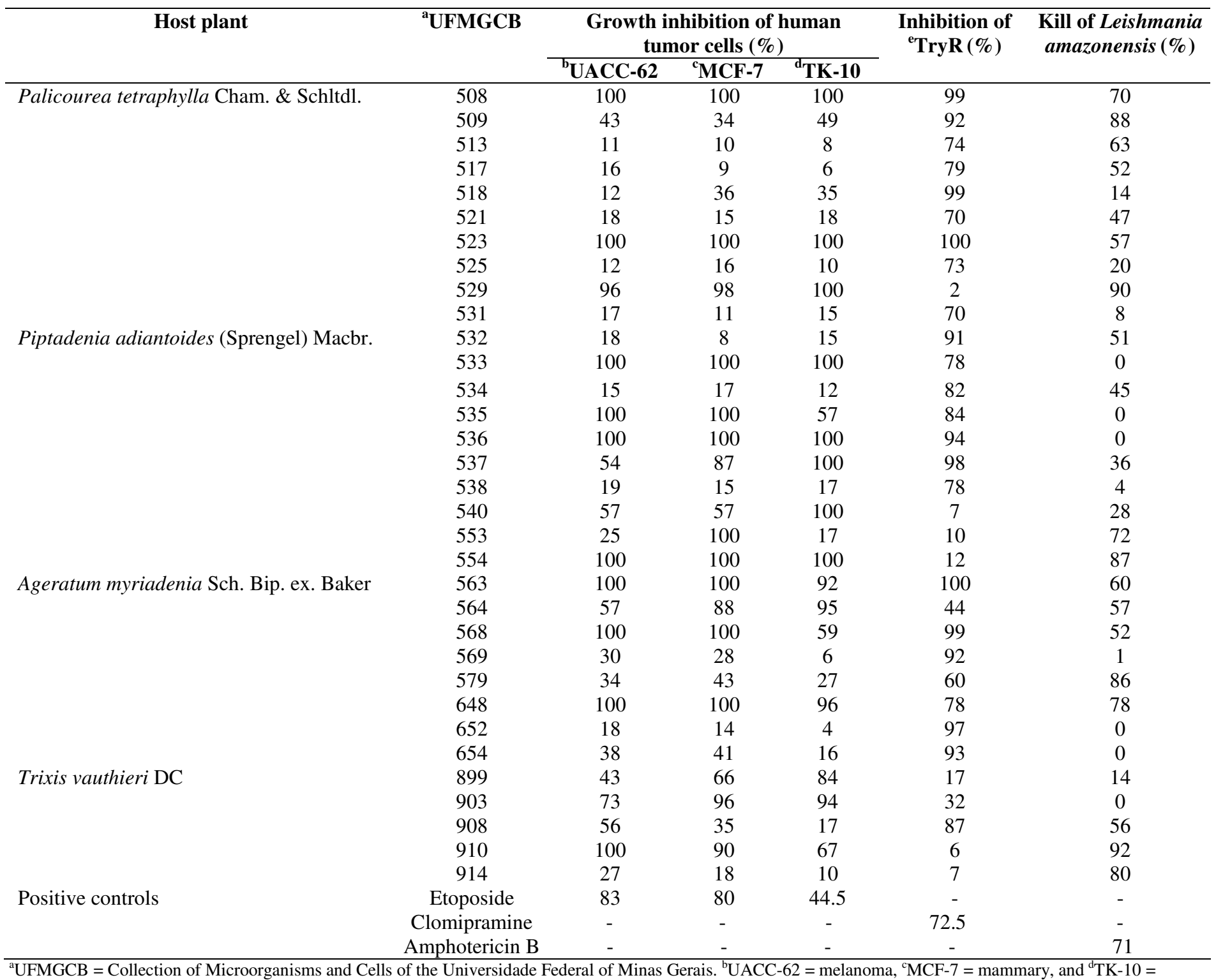

kidney. ${ }^{\text {T TryR }}=$ recombinant enzyme trypanothione reductase from Trypanosoma cruzi. 
Table 2. Fungal crude extracts active ( $\geq 90 \%$ ) against the recombinant enzyme trypanothione reductase (TryR) and tested against amastigote forms of Trypanosoma cruzi.

\begin{tabular}{ccc}
\hline${ }^{\mathbf{a}}$ UFMGCB code & Inhibition of ${ }^{\mathbf{b}}$ TryR $(\%)$ & Kill of Trypanosoma cruzi $(\%)$ \\
\hline 508 & 99 & 90 \\
518 & 99 & 0 \\
523 & 100 & 27 \\
532 & 91 & 0 \\
533 & 90 & 62 \\
536 & 94 & 60 \\
537 & 98 & 25 \\
563 & 100 & 0 \\
568 & 99 & 0 \\
654 & 93 & 0 \\
Clomipramine & 72.5 & - \\
Benznidazole & - & 73 \\
\hline
\end{tabular}

${ }^{\mathrm{a}} \mathrm{UFMGCB}=$ Collection of Microorganisms and Cells of the Universidade Federal of Minas Gerais. ${ }^{\mathrm{b}}$ TryR $=$ recombinant enzyme trypanothione reductase from Trypanosoma cruzi.

Table 3. Molecular identification based on sequencing of ITS region of endophytic fungi able to produce bioactive metabolites.

\begin{tabular}{|c|c|c|c|c|}
\hline $\begin{array}{l}\text { UFMGCB }^{\text {a }} \\
\text { code }\end{array}$ & $\begin{array}{c}\text { Closest related species/GenBank accession } \\
\text { number }\end{array}$ & $\begin{array}{c}\text { Maximum } \\
\text { identity }(\%)\end{array}$ & Identification & $\begin{array}{c}\text { GenBank accession } \\
\text { number }\end{array}$ \\
\hline 563 & Alternaria arborescens [AY154706] & 98 & A. arborescens & FJ466719 \\
\hline 513 & Arthrinium sp. [AJ279479] & 93 & Arthrium sp. & FJ466703 \\
\hline 521 & Arthrinium sp. [AJ279479] & 93 & Arthrium sp. & FJ466706 \\
\hline 509 & Arthrinium sp. [AM901699] & 93 & Arthrium sp. & FJ466702 \\
\hline 517 & Arthrinium sp. [AM922206] & 96 & Arthrium sp. & FJ466704 \\
\hline 525 & Arthrinium sp. [AM922206] & 98 & Arthrium sp. & FJ466708 \\
\hline 531 & Arthrinium sp. [AM922206] & 100 & Arthrium sp. & FJ466710 \\
\hline 532 & Arthrinium sp. [AM922206] & 98 & Arthrium sp. & FJ466711 \\
\hline 534 & Arthrinium sp. [AM922206] & 99 & Arthrium sp. & FJ466713 \\
\hline 535 & Arthrinium sp. [AM922206] & 99 & Arthrium sp. & FJ466714 \\
\hline 908 & Arthrinium sp. [AM922206] & 100 & Arthrium sp. & FJ466728 \\
\hline 911 & Arthrinium sp. [AM922206] & 97 & Arthrium sp. & FJ466729 \\
\hline 538 & Arthrinium sp. [AM922206] & 98 & Arthrium sp. & FJ466717 \\
\hline 564 & Bipolaris zeicola [FJ213843] & 95 & Bipolaris sp. & FJ466720 \\
\hline 554 & Cochliobolus melinidis [프071319] & 89 & Endophytic fungus. & FJ466718 \\
\hline 611 & Colletotrichum boninense [EU822802] & 98 & C. boninense & FJ466723 \\
\hline 914 & Fungal endophyte [EU687084] & 92 & Endophytic fungus & FJ466730 \\
\hline 899 & Fungal endophyte [EU687163] & 99 & Endophytic fungus & FJ466726 \\
\hline 903 & Fungal endophyte [EU687185] & 95 & Endophytic fungus & FJ466727 \\
\hline 529 & Fusarium oxysporum [DQ535184] & 99 & F. oxysporum & FJ466709 \\
\hline 533 & Gibberella sp. [EU552131] & 99 & Gibberella sp. & FJ466712 \\
\hline 536 & Gibberella sp. [EU552131] & 99 & Gibberella sp. & FJ466715 \\
\hline 648 & Gibberella sp. [EU552131] & 97 & Gibberella sp. & FJ466724 \\
\hline 518 & Penicillium citrinum [DQ123646] & 99 & P. citrinum & FJ466705 \\
\hline 579 & P. citrinum $[\mathrm{DQ} 123646]$ & 97 & P. citrinum & FJ466722 \\
\hline 654 & P. dipodomyicola [DQ339570] & 98 & P. citrinum & FJ466725 \\
\hline 523 & P. griseofulvum [FJ011548] & 99 & P. griseofulvum & FJ466707 \\
\hline 508 & Uncultured fungus [AJ877196] & 97 & Endophytic fungus & FJ466701 \\
\hline 537 & Uncultured fungus [AJ877196] & 98 & Endophytic fungus & FJ466716 \\
\hline 568 & Uncultured fungus [EF505005] & 98 & Endophytic fungus & FJ466721 \\
\hline
\end{tabular}

${ }^{a}$ UFMGCB $=$ Collection of Microorganisms and Cells of the Universidade Federal of Minas Gerais. 
Table 4. $\mathrm{IC}_{50}$ values of selected bioactive endophytic fungal extracts (tested in $\mu \mathrm{g} / \mathrm{mL}$ ).

\begin{tabular}{|c|c|c|c|c|c|c|}
\hline \multirow[t]{2}{*}{$\begin{array}{l}\text { Crude } \\
\text { extract }\end{array}$} & \multirow[t]{2}{*}{${ }^{\mathrm{a}} \mathrm{UFMGCB}$} & \multicolumn{3}{|c|}{$\begin{array}{l}\text { Growth inhibition of human tumor cells } \\
\qquad\left(\mathrm{IC}_{50}\right)\end{array}$} & \multirow[t]{2}{*}{$\begin{array}{l}\text { Kill of Trypanosoma } \\
\text { cruzi }\left(\mathrm{IC}_{50}\right)\end{array}$} & \multirow[t]{2}{*}{$\begin{array}{l}\text { Kill of Leishmania } \\
\text { amazonensis }\left(\mathrm{IC}_{50}\right)\end{array}$} \\
\hline & & ${ }^{\mathrm{b}} \mathrm{UACC}-62$ & ${ }^{\mathrm{c}} \mathrm{MCF}-7$ & ${ }^{\mathrm{d}} \mathrm{TK}-10$ & & \\
\hline 3645 & 508 & 5 & 1.5 & 2 & $>1$ & ${ }^{e} n t$ \\
\hline 3686 & 529 & 6.3 & 8 & 12.5 & $\mathrm{nt}$ & 9.8 \\
\hline 3693 & 533 & 1 & $<0.2$ & 1 & 10 & $\mathrm{nt}$ \\
\hline 3695 & 534 & nt & $<0.2$ & $\mathrm{nt}$ & $\mathrm{nt}$ & nt \\
\hline 3697 & 535 & 1 & nt & nt & 10 & nt \\
\hline 3699 & 536 & 1.2 & $<0.2$ & 1 & 10 & $\mathrm{nt}$ \\
\hline 3700 & 537 & $\mathrm{nt}$ & nt & 20 & $\mathrm{nt}$ & nt \\
\hline 3736 & 554 & 1.5 & $<0.2$ & 1.2 & nt & 24.4 \\
\hline 3966 & 563 & 20 & 8 & 20 & nt & $\mathrm{nt}$ \\
\hline 3967 & 564 & nt & nt & 1.5 & nt & nt \\
\hline 3968 & 568 & 1.6 & 20 & $\mathrm{nt}$ & nt & nt \\
\hline 3971 & 579 & $\mathrm{nt}$ & nt & $\mathrm{nt}$ & nt & 4.6 \\
\hline 4013 & 648 & 10 & 4 & 1.3 & $\mathrm{nt}$ & $\mathrm{nt}$ \\
\hline 4023 & 903 & nt & $<0.2$ & 25 & nt & nt \\
\hline \multirow[t]{4}{*}{4031} & 914 & nt & nt & nt & nt & 20 \\
\hline & Etoposide & 16 & 16 & 16 & nt & $\mathrm{nt}$ \\
\hline & Amphotericin B & nt & $\mathrm{nt}$ & $\mathrm{nt}$ & nt & 0.2 \\
\hline & Benznidazole & nt & nt & $\mathrm{nt}$ & 1 & $\mathrm{nt}$ \\
\hline
\end{tabular}

${ }^{\mathrm{a}} \mathrm{UFMGCB}=$ Collection of Microorganisms and Cells of the Universidade Federal of Minas Gerais; ${ }^{\mathrm{b}} \mathrm{UACC}-62=$ melanoma; ${ }^{\mathrm{C}} \mathrm{MCF}-7=$ mammary; ${ }^{\mathrm{d}}$ TK-10 $=$ kidney; ${ }^{\mathrm{e}} \mathrm{nt}=$ not tested.

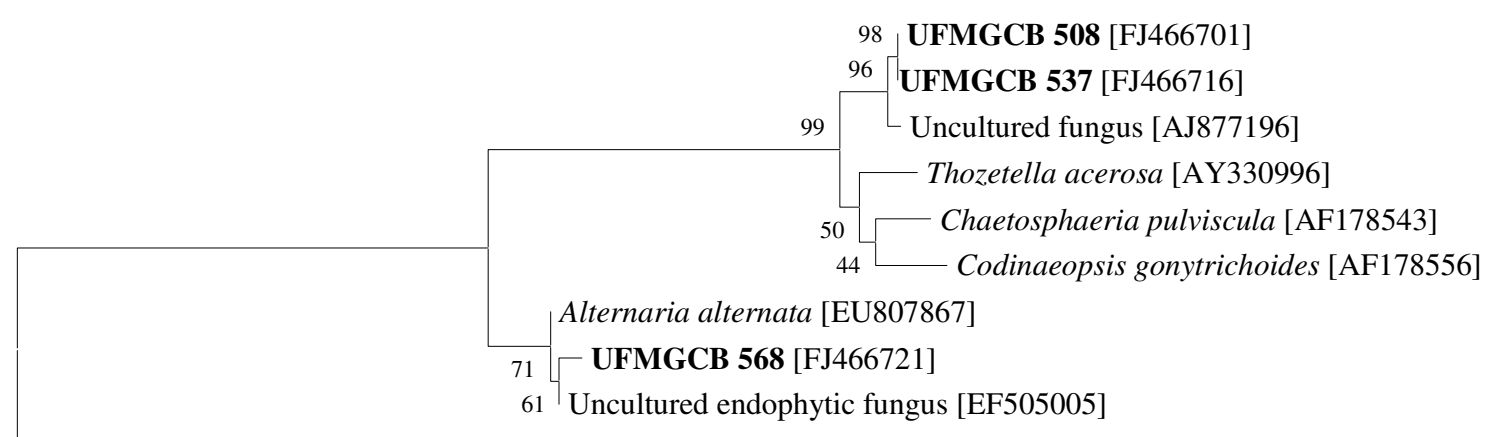

Trametes versicolor [AF042324]

0.1

Figure 1. Evolutionary tree showing the relationships among Endophytic fungi isolates UFMGCB 508, 537, and 568 and the next fungal sequences present in GenBank databases. The tree was constructed based on the rRNA gene sequence (ITS1-5.8S-ITS2) fragment sequence by using the neighbor-joining method. The numbers represent the percentage of 1,000 bootstrap replications in which a given branch appeared. The tree was rooted by making Trametes versicolor [AF042324] as outgroup. 


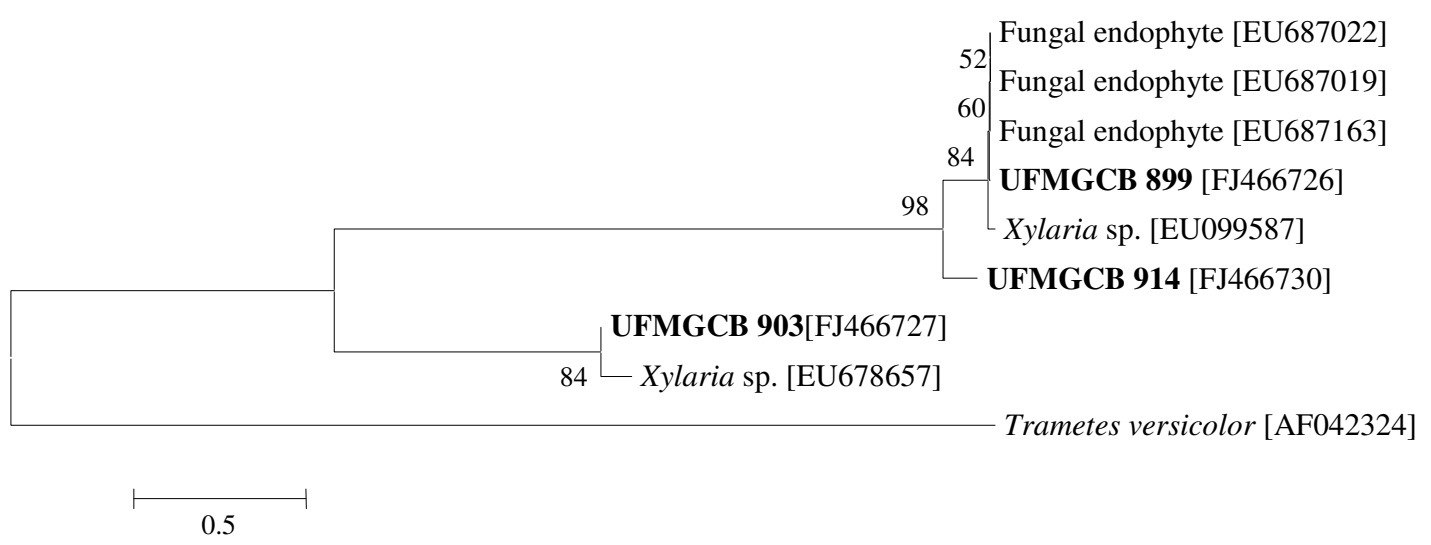

Figure 2. Evolutionary tree showing the relationships among Endophytic fungi isolates UFMGCB 899, 903 , and 914 and the next fungal sequences present in GenBank databases. The tree was constructed based on the rRNA gene sequence (ITS1-5.8S-ITS2) fragment sequence by using the neighbor-joining method. The numbers represent the percentage of 1,000 bootstrap replications in which a given branch appeared. The tree was rooted by making Trametes versicolor [AF042324] as outgroup.

\section{ACKNOWLEDGEMENTS}

To Prof. Alan Fairlamb for supplying the recombinant TryR enzyme used in this investigation, and RPPN Santuário of Caraça for help with the field plant collection. The work was financially supported by the FAPEMIG (Process CBB-APQ01122-08), CNPq, and FIOCRUZ.

\section{REFERENCES}

1. Altschul, S.F.; Madden, T.L.; Schaffer, A.A.; Zhang, J.H.; Zhang, Z.; Miller, W.; Lipman, D.J. (1997). Gapped BLAST and PSI-BLAST: a new generation of protein database search programs. Nucleic Acids Res. 25, 3389-3402.

2. Buckner, F.S.; Verlinde, C.L.M.J.; La Flamme, A.C.; Van Voorkhis, W.C. (1996). Efficient Technique for screening drugs for activity against Trypanosoma cruzi using parasites expressing beta-Galactosidase. Antimicrob Agent Chemother. 40, 2592-2597.

3. Borges, A.; Cunningham, M.L.; Tovar, J.; Fairlamb, A.H.(1995). Sitedirected mutagenesis of the redox-active cysteines of trypanosoma-cruzi trypanothione reductase. Eur J Biochem. 228, 745-752.

4. Costa, L.C.B.; Rocha, E.A.; Silva, L.A.M.; Jardim, J.G.; Silva, D.C.; Gaião, L.O.; Moreira, R.C.T. (2006). Levantamento preliminar das espécies vegetais com potencial econômico no Parque Municipal da Boa Esperança, Ilhéus, Bahia, Brasil. Acta Farm Bonaerense. 25, 184-91.
5. Cota, B.B.; Rosa, L.H.; Souza-Fagundes, E.M.; Martins-Filho, O.A.; Oliveira, R.C.; Romanha, A.J.; Rosa, C.A.; Zani, C.L. (2008a). A potent trypanocidal component from the fungus Lentinus strigosus inhibits trypanothione reductase and modulates PBMC proliferation. Mem Inst Oswaldo Cruz. 103, 263-270.

6. Cota, B.B.; Rosa, L.H.; Caligiorne, R.B.; Rabello, A.; Rosa, C.A.; Zani, C.L. (2008b). Altenusin, a biphenyl isolated from the endophytic fungus Alternaria sp. inhibits trypanothione reductase from Trypanosoma cruzi. FEMS Microbiol Lett. 285, 177-182.

7. De Nijs, M.; Rombouts, F.; Notermans, S. (2007). Fusarium molds and their mycotoxins. J. Food Safety. 16, 15-58.

8. Duke, J.A.; Wain, K.K. (1981). Medicinal plants of the world. Computer index with more than 85,000 entries.

9. Gao, X.X.; Zhou, H.; Xu, D.Y.; Yu, C.H.; Chen, Y.Q.; Qu, L.H. (2005). High diversity of endophytic fungi from the pharmaceutical plant, Heterosmilax japonica Kunth revealed by cultivation-independent approach. FEMS Microbiol. Lett. 249, 55-266.

10. Hamilton, C.J.; Saravanamuthu, A.; Eggleston, I.M.; Fairlamb, A.H. (2003). Ellman's-reagent-mediated regeneration of trypanothione in situ: substrate economical microplate and time-dependent inhibition assays for trypanothione reductase. Biochem. J. 369, 529-537.

11. Hartwell, J.L. (1971). Plants used against cancer: a survey. Lloydia. 34,103-160.

12. Huang, Y.; Wang, J.; Li, G.; Zheng, Z.; Su, W. (2001). Antitumor and antifungal activities in endophytic fungi isolated from pharmaceutical plants Taxus mairei, Cephalataxus fortunei and Torreya grandis. FEMS Immunol. Med. Microbiol. 31, 163-167. 
13. Inácio, M.L.; Silva, G.H.; Teles, H.L.; Trevisan, H.C.; Cavalheiro, A.J.; Bolzani, V.S.; Young, M.C.M.; Pfenning, L.H.; Araújo, A.R. (2006). Antifungal metabolites from Colletotrichum gleosporioides, an endophytic fungus in Cryptocarya mandioccana Nees (Lauraceae). Biochem. Syst. Ecol. 34, 822-824.

14. Kuldau, G.A.; Yates, I.E. (2000) Evidence for Fusarium endophytes in cultivated and wild plants. In: Bacon, C.W.; White Jr., J.F. (eds). Biology and evolution of microbial endophytes. Dekker, New York, USA, p.85117.

15. Liu, C.H.; Zou, W.X.; Lu, H.; Tan, R.X. (2000). Antifungal activity of Artemisia annua endophyte cultures against phytopathogenic fungi. $J$. Biotechn. 88, 277-282.

16. Márquez, S.S.; Bills, G.F.; Zabalgogeazcoa, I.A. (2007). The endophytic mycobiota of Dactylis glomerata. Fungal Div. 27, 171-195.

17. Monks, A.; Scudiero, D.; Skehan, P.; Shoemaker, R.; Paull, K.; Vistica, D.; Hose, C.; Langley, J.; Cronise, P.; Vaigro-Wolff, A.; Gray-Goodrich, M.; Campbell, H.; Mayo, J.; Boyd, M. (1991). Feasibility of a high-flux anticancer drug screen using a diverse panel of cultured human tumor cell lines. J. Nat. Cancer Inst. 83. 757-766.

18. Montemurrom, N.; Visconti, A. (1992). Alternaria metabolites chemical and biological data. In: Chelkowski J, Visconti A (eds). Alternaria: Biology, Plant disease and Metabolites. Elsevier, Amsterdam, p.449-557.

19. Pan, J.J.; Baumgarten, A.M.; May, G. (2008). Effects of host plant environment and Ustilago maydis infection on the fungal endophyte community of maize (Zea mays). New Phytol. 178, 147-156.

20. Phongpaichit, S.; Nikom, J.; Rungjindamai, N.; Sakayaroj, J.; HutadilokTowatana, N.; Rukachaisirikul, V.; Kirtikara, K. (2006). Biological activities of extracts from endophytic fungi isolated from Garcinia plants. FEMS Immunol. Med. Microbiol. 51, 517-525.

21. Qian-Cutrone, J.; Gao, Q.; Huang, S.; Klohr, S.E.; Veitch, J.S.; Shu, Y.Z. (1994). Arthrinone, a Novel Fungal Metabolite from Arthrinium sp. FA 1744. J. Nat. Prod. 57, 1656-1660.

22. Ribeiro, A.; Pilo-Veloso, D.; Howarth, O.; Zani, C.L. (1999). A new cyclohexadecane derivative from Trixis vauthieri DC (Asteraceae). Org. Lett. 1, 1897-1900.

23. Rosa, L.H.; Cota, B.B.; Machado, K.M.G.; Rosa, C.A.; Zani, C.L. (2005). Antifungal compound produced by Oudemansiella canarii (Basidiomycota). World J. Microbiol. Biotechnol. 21, 983-987.

24. Rosa, L.H.; Machado, K.M.G.; Jacob, C.C.; Capelari, M.; Rosa, C.A.; Zani, C.L. (2003). Screening of Brazilian basidiomycetes for antimicrobial activity. Mem. Inst. Oswaldo Cruz. 98, 967-974

25. Rosa, L.H.; Souza-Fagundes, E.M.; Machado, K.M.G.; Alves, T.M.A.; Martins-Filho, A.O.; Romanha, A.J.; Oliveira, R.C.; Rosa, C.A.; Zani, C.L. (2006). Cytotoxic, immunosuppressive and trypanocidal activities of agrocybin, a polyacetylene produced by Agrocybe perfecta (Basidiomycota). World J. Microbiol. Biotechnol. 22, 539-545.

26. Schulz, B.; Boyle, C.; Draeger, S.; Römmert, A.K.; Krohn, K. (2002). Endophytic fungi: a source of novel biologically active secondary metabolites. Mycol. Res. 106, 996-1004.

27. Scio, E.; Ribeiro, A.; Alves, T.M.A.; Romanha, A.J.; Dias, S.F.J.; Cordell, G.A.; Zani, C.L. (2003). Diterpenes from Alomia myriadenia (Asteraceae) with cytotoxic and trypanocidal activity. Phytochem. 64, 1125-1131.

28. Souza, A.Q.L.; Souza, A.D.L.; Filho, S.A.; Pinheiro, M.L.B.; Sarquis, M.I.M.; Pereira, J.O. (2004). Antimicrobial activity of endophytic fungi isolated from amazonian toxic plants: Palicourea longiflora (Aubl.) Rich and Strychnos cogens Bentham. Acta Amaz. 34, 185-195.

29. Strobel, G. (2002). Rainforest endophytes and bioactive products. Crit. Rev. Biotechnol. 22, 315-33

30. Tamura, K.; Dudley, J.; Nei, M.; Kumar, S. (2007). MEGA4: Molecular Evolutionary Genetics Analysis (MEGA) software version 4.0. Mol. Biol. Evol. 24,1596-1599.

31. Teixeira, M.C.; Jesus, S.R.; Sampaio, R.B.; Pontes, C.L.; Santos, W.L. (2002). A simple and reproducible method to obtain large numbers of axenic amastigotes of different Leishmania species. Parasitol. Res. 88, 963-968.

32. Wang, F.W.; Hou, Z.M.; Wang, C.R.; Li, P.; Shi, D.H. (2008). Bioactive metabolites from Penicillium sp., an endophytic fungus residing in Hopea hainanensis. World J. Microbiol. Biotechnol. 24, 2143-2147.

33. White, T.J.; Bruns, T.D.; Lee, S.B.; Taylor, J.W. (1990). Amplification and direct sequencing of fungal ribossomal RNA genes for phylogenetics. In Gelfand, N.A.; Gelfand, J.; White, T.J. (eds). PCR protocols: A guide of methods and applications. Academic Press, San Diego, CA, USA, p.315-322.

34. Xiao, J.Z.; Tsuda, M.; Doke, N.; Nishimura, S. (1991). Phytotoxins produced by germinating spores of Bipolaris oryzae. Phytopathol. 81, 58-64.

35. Yuan, Z.; Chen, Y.; Yang, Y. (2009). Diverse non-mycorrhizal fungal endophytes inhabiting an epiphytic, medicinal orchid (Dendrobium nobile): estimation and characterization. World J. Microbiol. Biotechnol. 25, 295-303. 